\title{
Alcohol and drugs in adolescence: work process in health in school program
}

\author{
Bruna Luiza Matos Coutinho', Amanda Alves Feitosa ${ }^{1}$, Camila Bantim Cross Diniz' \\ José Lucas Souza Ramos², Larissa Zuqui Ribeiro², Sheila Rodrigues Amorim², \\ Caroline Feitosa Dibai de Castro², Italla Maria Pinheiro Bezerra²
}

DOI: http://dx.doi.org/10.7322/jhgd.127646

\begin{abstract}
Introduction: Adolescence is characterized as a transition period between childhood and adult life that imposes great physical, cognitive and psychosocial changes. During that period, the adolescent is exposed and vulnerable to the consumption of alcohol and drugs, and has been an scenery where nurses who works in the School Health Programs (SHP) interact with them. In this sense, the interaction between education and health can influence adolescents to become questioners of the risks they are exposed and look together for better options to improve their quality of life.

Objective: To analyse the perception and health practices of Nurses working in the School Health Programs of prevention of alcohol and drugs during adolescence.

Methods: This is a descriptive and qualitative study carried out in the city of Juazeiro do Norte, Ceará, Brazil, with 18 nurses participating in the SHP, who implement actions with adolescents in schools. The data collection took place through a semi structured interview and their organization through thematic analysis.

Results: The participants affirmed that the importance of their actions and work is directed to prevent the use of alcohol and drugs among adolescents, excluding the precepts of health promotion. They pointed out that the interaction between education and health is characterized as an effective strategy in the prevention of damages caused by the use of alcohol and drugs, emphasizing the participation of family members during the process of elaboration, application and continuity. It was also evidenced that the educational practices are performed mostly through lectures, characterizing a work centred on clinical, individual and curative practice.

Conclusion: Nurses understand that the interaction between health and education is an effective strategy to prevent the use of alcohol and drugs in adolescents, emphasizing the importance of family participation in the process of construction and support of this context. However, it is possible to identify that the actions developed by these professionals are still restricted to modify some behaviours such as to improve their willing of sharing new knowledge.
\end{abstract}

Keywords: adolescents, drugs, health in school program, nurse.

\section{INTRODUCTION}

Adolescence is a period characterized by physical, emotional and social changes, being conducive to the formation of habits and behavioural patterns ${ }^{1}$. According to the World Health Organization, this phase comprises the age group of 10 to 19 years of age $^{2}$.

Physical, emotional and social transformations recur during this period, and promote various changes in the way of thinking and acting, reflecting on the performance of their social roles. This is achieved by the numerous situations imposed on the teenager, permeating in doubt about what future to follow. The hormonal shock, the end of the infant stage and the transition to adulthood ${ }^{2,3}$.

Faced with this, the adolescent becomes vulner-

\footnotetext{
1 Bacharel em Enfermagem. Faculdade de Juazeiro do Norte, Ceará, Brasil.

2 Espaço de Escrita Científica da Emfermagem. Escola Superior de Ciências da Santa Casa de Misericórdia de Vitória, EMESCAM. Correspondig author: Italla Maria Pinheiro Bezerra. - E-mail: italla.bezerra@emescam.br
} 
able to various "temptations" proposed by the society, which highlights the use of alcohol and drugs, these events exposed by the characteristics of this phase, generate a concern of public bodies ${ }^{3}$.

The literature stands out that adolescents are among the main public who consume this type of substance, such as Quental et al. ${ }^{4}$ research shows, that among schoolchildren, 65\% report using alcohol abusively, becoming a addiction. Zeitoune et al..$^{5}$ mention that adolescents and adults are more susceptible to their use, a fact, which can hinder personal development, as these defined "drug abuse", alter the physiological, psychological and immunological functions of the body in a transitory or permanent manner.

In this context, in order to meet the principles of the Unified Health System, through the precepts of health promotion and prevention, it is understood that the Family Health Strategy (FHS) is the ideal place to follow up these cases; there is a good approach of health professionals in the community ${ }^{2}$.

The FHS uses strategies based on programs that aim to bring the public closer to its actions, in this sense, by understanding that the school is one of the appropriate places to adjust prevention and promotion work of alcohol and drug use, those are important characteristics that contribute to the diffusion of such perspective in the community and society.

Therefore, the Health in School Program was established to support the implementation of projects that incorporate health and education for the same client group, collaborating in the integration of the community with the school ${ }^{1}$.

So that the program objectives are achieved, different strategies are used, among them health education, being a unique opportunity for the work of nurses ${ }^{3}$.

The nurse, faced with this scenario, has the ability to integrate into the school, adding knowledge for Health and Education Promotion, before discourses that lead to critical reflection, integrating experiences and learning of all involved. All this interaction between education and health can positively influence students to become questioners about the risks to which they are exposed in all spheres of society, generating the possibility of achieving together a better quality of life and healthy adolescence ${ }^{3}$.

Faced with the discussion about the topic, was questioned: How has been the nurse's action and intervention in relation to the use of alcohol and drugs by adolescents? Considering that this is an intersectoral policy, the object of study proposed here intends to investigate the practices of nurses working in the Health Program at School, taking as a reference actions related to the use of alcohol and drugs among adolescents.

Because, is still limited the literature published of studies based on actions developed by nurses regarding the consumption of alcohol and drugs by adolescents at school stage, the need for studies in this subject is awakened, considering that this is a public health problem which is bringing negative consequences for the community.

Based on this study, it is believed, the health actions developed by nurses in relation to alcohol and drug use by adolescents become increasingly expanded, so that they can significantly reduce both the physical and social consequences produced by its abusive use.

Therefore, the present study aimed to analyse the perception and professional practice of Nurses working actively in School Health Programs, against the use of alcohol and drugs in adolescence.

\section{METHODS}

This is a descriptive study with qualitative approach, carried out in the city of Juazeiro do Norte, Ceará, Brazil, with the Family Health Teams enrolled in the School Health Program.

The municipality of Juazeiro do Norte has 67 Family Health Team, of which 62 participate in School Health Program. Therefore, the subjects of the study were selected based on the premise that they have at least six months of experience working in the SHP, then applying the process of speech saturation, resulting in a total of 18 nurses.

Thus, the process of saturation of the lines was observed when the subjects stressed the importance of the nursing role and the interaction between education and health in the use of alcohol and drugs among adolescents, and actions for prevention, in stating that "actions are important for the prevention of alcohol and drugs" and "predominance of a vision focused on preventive actions for the use of alcohol and drugs, in order to develop a reflection and critical awareness among these adolescents about the damage".

With regard to strategies and planning of health actions, there was saturation when the testimony illustrated the "pedagogical approach centred on lectures, with the transmission of unidirectional information".

Data collection was performed between August and October 2015, where a semi-structured questionnaire was used, seeking to understand the perception of the nurse professional regarding the use of alcohol and drugs by adolescents; the planning with the health team in the SHP and elements that facilitate and hinder the application of the process. The interviews were recorded and transcribed.

For the organization and analysis of the data was used the content analysis technique proposed by Bardin, cited by Silva and Fossá ${ }^{6}$ in the content analysis technique, following the steps: pre-analysis, material exploration, treatment of results and interpretation.

Following the above steps for organizing and analysing data, the fluctuating reading was held, where the documents were arranged for the constitution of the corpus of the research consisted of 18 interviews with the nurses.

With the construction of the corpus, it was operationalized encodings, identifying the units of records and context units. These were found in the speeches, by means of words, which were grouped according to their similarities and meanings identified, as described in the table below (Table 1).

The project was submitted to the Research Ethics Committee of the Faculty of Juazeiro do Norte, obtaining an approval opinion, under No. 1,342,465 of Novem- 
Tabel 1: Record units, context units and analytical categories according to Bardin's technique. Juazeiro do Norte, Ceará 2015

\begin{tabular}{ccc}
\hline Record units & Context units & Analytical categories \\
\hline $\begin{array}{c}\text { Preventive practices; Training of } \\
\text { these professionals; Continuing } \\
\text { education. }\end{array}$ & $\begin{array}{c}\text { Performance focused on the } \\
\text { prevention of alcohol and drug } \\
\text { use, without focusing on health } \\
\text { promotion, having as a factor } \\
\text { for this conduct, the training of } \\
\text { these professionals. }\end{array}$ & $\begin{array}{c}\text { Importance of nursing performan- } \\
\text { ce regarding the use of alcohol } \\
\text { and drugs among adolescents. }\end{array}$ \\
$\begin{array}{c}\text { Development of promotional } \\
\text { involvement; Individual and } \\
\text { collective needs. }\end{array}$ & $\begin{array}{c}\text { actions with the participation of } \\
\text { family members, meeting } \\
\text { individual and collective needs. }\end{array}$ & $\begin{array}{c}\text { Interaction between Education } \\
\text { and Health. }\end{array}$ \\
Anidirectional transmission; & $\begin{array}{c}\text { Actions focused on } \\
\text { unidirectional transmission, } \\
\text { using as main strategy the } \\
\text { lecture and without dynamic } \\
\text { planning of health actions. }\end{array}$ & Strategies and Planning of health \\
actions.
\end{tabular}

ber 29, 2015. The ethical legal aspects of the resolution 466/12 from the National Health Council were obeyed.

RESULTS AND DISCUSSION

Eighteen nurses participated in this study, out of them
17 are female and one is male, with ages ranging from 24 to 55 years, and experience time between two and 28 years.

After analysing the results, it was possible to list three categories, namely: the importance of nursing performance in relation to alcohol and drug use among adolescents; interaction between education and health; and

Table 2: Description of study categories and evidence. Juazeiro do Norte, Ceará, 2015

\begin{tabular}{cc}
\hline Study categories & Analytical categories \\
\hline $\begin{array}{c}\text { Importance of nursing performance regarding the } \\
\text { use of alcohol and drugs among adolescents. }\end{array}$ & $\begin{array}{c}\text { Perception of the professionals about the } \\
\text { importance of the action against the use of alcohol } \\
\text { and drugs by adolescents focused on prevention } \\
\text { actions. }\end{array}$ \\
Interaction between Education and Health. & $\begin{array}{c}\text { Actions aimed at preventing the use of alcohol and } \\
\text { drugs, with the participation of adolescents and } \\
\text { their families. }\end{array}$ \\
Strategies and Planning of health actions. & $\begin{array}{c}\text { Transmission of information through lectures, wi- } \\
\text { thout carrying out a dynamic planning of actions. }\end{array}$
\end{tabular}

strategies and planning of health actions, as described in the table below (Table 2).

Health and nursing in the school context: the use of alcohol and drugs by adolescents

It is necessary to discuss the dimensions, complexities and implications for the physical, psychological and social health of adolescents and society as a whole. In this sense, it is understood that the nursing professional, through the strategies carried out by the FHS and the SHP can act against the abuse of alcohol and drugs among adolescents, recognizing within their reality the real consequences of their use ${ }^{5}$.

The nurses interviewed affirm that the importance of their intervention is summarized in actions to prevent the use of the substances addressed, listing this process and its importance for a healthy life, as described in the following statements:

"Very important, because the actions taken with the Family health support center, aimed to warn these adolescents about the health risks caused by the use of alcohol and drugs [...]" Enf. 4

"The nursing action against the use of alcohol and drugs by adolescents is of great importance because this audience does not have the maturity to 
measure the effects produced by the use of these substances [...]" Enf. 7

"Important educational strategy in order to clarify the effects of alcohol and drug use..." Enf. 14

"Of great importance, as it contributes to a healthy life, away from risk, but it is a topic that has not been addressed in the program." Enf. 15

It is important to understand that nurses must comprehensively cover their actions and meet all pre-established perspectives, aiming at comprehensive care for the patient, in its various biopsychological aspects. In adolescent health, in treatment of drug and alcohol, nursing should conduct an analysis, seeking to act in the prevention, control and treatment, directing attention also to the family and the community ${ }^{5}$.

Therefore, it is understood that Health Education makes it possible to reach these goals, since it is a strategy that awakens the empowerment of the user through educational actions, providing for the adolescent a reflexive process that can intervene in health indicators, avoiding greater consequence of damage, then covering the other members who are close to this public ${ }^{3}$.

It is important to highlight that an interdisciplinary and multidisciplinary work is key, requiring that all primary care professionals participate in the process to better planning and implementation of activities ${ }^{7}$.

It is necessary that the professionals are able to interact with this vulnerable population, considering that is exposed to constant biopsychological changes. Continuing education is one of the main challenges that have been faced, as it seeks to break a biomedical barrier imposed on health services, arising from the traditional model of care $^{4,8}$.

Permanent education, in turn, has become a barrier to health services, as it also refers to the training of health workers trained to understand and respond to the needs of different social groups, so that it can guarantee the health rights and introduce in undergraduate curricula the concept of integrated care, breaking with the formation pointed to the clinical model ${ }^{8}$.

Initial training of these professionals end up taking them to a distant action of health promotion; this is due to the focus still predominantly biologicist, curative, medical-centred and disarticulated of health practices 9 .

In this way, the need to promote changes through the inclusion of concepts such as interdisciplinary and intersectoriality, subject empowerment and quality of life are highlighted, which are understood as elements that must sustain a new practice of formation and performance, having as reference the health promotion ${ }^{10}$.

The continuing education of these professionals also reveals itself as an important factor for the promotion of changes in the nurses' way of acting, making possible a collective work with all those involved in the actions, in order to transmit and absorb knowledge, experiences and learning, as also adequately respond to the complexity of the problems encountered in health reality in its service scope $^{7,10,11}$.

When talking about health in the school environ- ment, still there are difficulties of interaction between the public sectors of health and education, which must go hand in hand for effective action. However, in order to achieve these actions, in a perspective of adolescent health promotion, it is important that health and education professionals have a uniformity in their discourse, aiming to promote health education, emphasizing the specific actions considered important in the school period ${ }^{11}$.

Among the most important challenges for health promotion in schools, the Brazilian Ministry of Health points out the technical instrumentation of teachers, employees and professionals of the Family Health Strategy (FHS), in the sense of supporting and strengthening initiatives that allow an improvement in the quality of life of adolescents $^{12}$.

\section{Education and health as a tool to promote health in adolescents in the use of alcohol and drugs}

One of the strategies used by the FHS in empowering the community to perform self-care and coping with the health-disease process are educational actions. This interaction is used as an exchange tool between empirical and scientific knowledge, in order to reconstruct everyday meanings and attitudes ${ }^{13,14}$.

Thus, the interaction between education and health makes it possible for the population to acquire knowledge and skills, so as to realize healthy choices about life, helping to raise awareness of the policy and environmental changes that promote better health ${ }^{13,14}$.

In analysing this interaction, it is possible to identify in the statements below that nurses believe that prevention through counselling is the main way to provide better health care, in addition to recognizing their role and importance in the school context.

"Education and health must walk together, because if you have a job from prevention, certainly will avoid the contact of these adolescents with alcohol and drugs [...]" Enf. 2.

"When the nurse enters the school, he is a distinguished professional of their experience, so that interaction between education and health is important, because they see another way, a committed professional with them [...]" Enf. 3.

"Education is everything, has a principle of opinion forming, however, required the integration of families in the developed actions, because is not just to educate teens and leave their base which is the family with no information [...]" Enf. 4

"Educational strategies serve to guide adolescents, show what paths they must follow, but everything will depend on their willingness to make the right choice [...]" Enf. 9

In this context, considering the participation as an element that sets the interaction nurse/user in the educational process, corroborates with Machado, Haddad and Zoboli $^{15}$ by stating that although it is the right and duty 
of the population, the individual and collective participation in the execution of their care should be stimulated by professionals in different moments and contexts of work, distributing themselves in health services, community, or school context.

In this sense, through the curricular guidelines of the undergraduate-nursing course, pedagogical projects have been expanded, which encourage popular participation in the process of health promotion and treatment. This objective perspective is that the care provided to community manages satisfaction and improves the quality of life of users ${ }^{16}$.

Interviewed professionals believe that the interaction between education and health can be used as an effective strategy to prevent alcohol and drug use among adolescents. Considering that from the interventions carried out by education and health, a critical reflection can be developed that comes from adolescents, on the damages caused by the use of alcohol and drugs, consequently, it is possible to improve the quality of life.

Therefore, the family becomes an important point of support for the formation of values and principles of adolescents, because in their association, are transmitted the first moral rules that will guide them in their social life, influencing directly in their development ${ }^{5}$.

However, in order to achieve the goals of health education activities, it is necessary for the professional to be able to perform such practices, appropriating the technical and empirical knowledge of this public, since this is considered essential, in order to recognize the reality of the other, as well as the interaction and the construction of the collective form of knowledge and community daily practices $^{13,14}$

Thus, the interaction between education and health is proving to be an important tool, facilitating community empowerment and contributing significantly to the promotion of health ${ }^{13,14}$.

\section{Health promotion actions: Planning strategies}

Health professionals face daily difficulties in the sectors of their educational assistance, these originate from the biomedical model, which is still prevalent in health services. This dilemma directly influences the health education activities, as only restricted to specific actions, to change inappropriate behaviour, and adopting an authoritarian model, where professional reviews the content, making the population only hearers of this pro$\operatorname{cess}^{17-21}$.

In this way, is sought to understand the strategies used by nurses in the implementation of educational actions. It were evidenced actions focused on clinical, individual and curative practice, where these are focused on conducting lectures, group dynamics, which are often limited by the lack of didactic and financial resources.

"[...] We try to plan the actions using teaching materials, building dynamic [...]". "Through meetings between the health team and school managers. " Enf.2

"[...] The strategies are summarized in educational activities such as lectures, but the lack of teaching resources leaves us limited to carrying out the actions." Enf. Referring to Fig.
"Educational lectures" "First the health department makes a meeting with the school principals and the health team for programming actions." Enf. 13

"These actions are carried out through conversation circles and lectures for the target audience and parents" "These actions are planned through schedules and target group approach in the social areas exposed" Enf. 17

It is identified that the nurses interviewed, still limit their work process in actions centred on the transmission of knowledge in a unidirectional way. However, it was observed, in a less significant way, that some professionals are concerned with health actions that seek to exchange experience between professionals and the community, allowing a greater participation of them during the accomplishment of the actions.

The lectures are one of the main strategies used by the professionals to carry out the educational actions, being part of the proposal of continuing education. These have a unidirectional character, characterized by the display of technical information without active participation of the target audience, playing a receiver role of information ${ }^{18-20}$.

Thus, it is necessary to restructure educational actions through a dynamic planning process, where the nurse performs evaluations of the actions to be developed, observing the reality and the interest of the assisted population. After this step, define the best educational method, and thus the health education activities are addressed in a proposal for shared construction of knowledge, seeking interdisciplinarity, autonomy and citizenship, with the protagonist, the population ${ }^{19-21}$.

To establish a health education processes to create bindings, transformative and effective relationship, the technical training of professionals can not be understood as an acquisition of rigid instruments and techniques, and generalizing them in their educational actions. Therefore, it is understood that should happen constant criticism by professional reflections about their educational practices, making it applicable to their dynamic context ${ }^{18,20}$.

Academic education and the lack of technical and practical preparation are the main contributors to these actions, given that the interviewees consider the public and the subject as difficult points to work, strengthening their insecurity and lack of preparation.

It is believed that this study contributes to a reflection about the nursing action facing the theme in practice, thus enabling the construction of a new look, based on integrative and educational relations, making permanent education a viable option for these interventions meet the needs of groups. It is necessary a dynamic planning, with the adoption of educational practices of dialogical character, capable of promoting the active participation of the adolescents, aiming at the protagonism and co-responsibility.

Therefore, the interventions at early ages is very important, and that those, being developed in an interdisciplinary and intersectoral way, having as reference the health promotion and thus, an improvement in the adolescent health quality. 


\section{CONCLUSION}

Nurses understand that the interaction between health and education is an effective strategy to prevent the use of alcohol and drugs among the adolescents, emphasizing the importance of family participation in the process of construction and support of this context. However, it is possible to identify that the actions developed by these professionals are still restricted to the modification of some behaviours, such as to improve the willing of sharing new knowledge.

\section{REFERENCES}

1. Giacomozzi Al, Itokasu MC, Luzardo AR, Figueiredo CDS, Vieira M. Levantamento sobre uso de álcool e outras drogas e vulnerabilidades relacionadas de estudantes de escolas públicas participantes do programa saúde do escolar/saúde e prevenção nas escolas no município de Florianópolis. Saúde Soc. 2012;21(3):612-22. DOI: http://dx.doi.org/10.1590/S0104-12902012000300008

2. Almeida JRS, Oliveira NC, Moura ERF, Sabóia VPA, Mota MV, Pinho LGM. Oficinas de promoção de saúde com adolescentes: relato de experiência. Rev Rene. 2011;12(n. esp.):1052-8.

3. Beserra EP, Sousa LB, Alves MDS. Intervenção educativa utilizando a atividade de vida respiração com adolescentes. Esc Anna Nery. 2014;18(2):209-14. DOI: http://dx.doi.org/10.5935/1414-8145.20140030

4. Quental OB, Feitosa ANA, Lacerda SNB, Assis EV, Isidório UA, Abreu LC. Prevalence of alcohol use among adolescent students. J Nurs UFPPE. 2015;9(1):91-7. DOI: http://dx.doi.org/10.5205/r euol.681760679-1-ED.0901201513

5. Zeitoune RCG, Ferreira VS, Silveira HS, Domingos AM, Maia AC. O conhecimento de adolescentes sobre drogas lícitas e ilícitas: uma contribuição para a enfermagem comunitária. Esc Anna Nery. 2012;16 (1):5763. DOI: http://dx.doi.org/10.1590/S1414-81452012000100008

6. Silva AH, Fossá MIT. Análise de conteúdo: exemplo de aplicação da técnica para análise de dados qualitativos. Qualitas Rev Eletr. 2015; 17(1). DOI: http://dx.doi.org/10.18391/qualitas.v16i1.2113

7. Bezerra IMP, Alves SAA, Machado MFAS, Zioni F, Antão JYFL, Martins AAA, et al. Health Education For Seniors: An Analysis In Light Of Paulo Freire's perspective. Int Archiv Med, 2015; 8(28):1-9. DOI: http:// dx.doi.org/10.3823/1627

8. Almeida AH, Soares CB. Ensino de educação nos cursos de graduação em enfermagem. Rev Bras Enferm. 2010;63(1):111-6.

9. Chiesa AM, Nascimento DDG, Braccialli LAD, Oliveira MAC, Ciampone MHT. A formação de profissionais da saúde: Aprendizagem significativa à luz da promoção da saúde. Cogitare Enferm. 2007;12(2):236-40.

10. Silva KL, Sena RR, Grillo MJC, Horta NC. Formação do enfermeiro: desafios para a promoção da saúde. Esc Anna Nery Rev Enferm. 2010;14(2):368-76.

11. Pierobon M, Barak M, Hazrati S, Jacobsen KH. Alcohol consumption and violence among Argentine adolescentes. J Pediatr (Rio J). 2013; 89(1):100-7. DOI: http://dx.doi.org/10.1016/j.jped.2013.02.015

12. Santiago LM, Rodrigues MTP, Oliveira Junior AD, Moreira TMM. Implantação do Programa Saúde na escola em Fortaleza-CE: atuação de equipe da Estratégia Saúde da Família. Rev Bras Enferm. 2012;65(6):10269. DOI: http://dx.doi.org/10.1590/S0034-71672012000600020

13. Cervera DPP, Parreira BDM, Goulart BF. Educação em saúde: percepção dos enfermeiros da atenção básica em Uberaba (MG). Ciênc Saúde Coletiva. 2011; 16(Supl. 1):1547-54. DOl: http://dx.doi.org/10.1590/ S1413-81232011000700090

14. Leite CT, Machado MFAS, Vieira RP, Marinho MNSB, Monteiro CFS. The school health program: teachers' perceptions. Invest Educ Enferm. 2015;33(2):280-7. DOI: http://dx.doi.org/10.1590/S012053072015000200010

15. Machado EP, Haddad JGV, Zoboli ELCP. A comunicação como tecnologia leve para humanizar a relação enfermeiro-usuário na Atenção Básica. Rev Bioethikos. 2010;4(4):447-52.

16. Fernandes JD, Silva RMO, Teixeira GA, Florencio RMS, Silva LS, Rebouças LCC. Aderência de cursos de graduação em enfermagem às diretrizes curriculares nacionais na perspectiva do sistema único de saúde. Esc Anna Nery Rev Enferm. 2013;17(1):82-9. DOI: http://dx.doi.org/10.1590/S141481452013000100012

17. Alves GG, Aerts D. As práticas educativas em saúde e a Estratégia Saúde da Família. Ciênc Saúde Coletiva. 2011;16(1):319-25. DOI: http://dx.doi.org/10.1590/S1413-81232011000100034

18. Silva CP, Dias MSA, Rodrigues AB. Práxis educativa em saúde dos enfermeiros da Estratégia Saúde da Família. Ciênc Saúde Coletiva. 2009;14(Supl. 1):1453-62. DOI: http://dx.doi.org/10.1590/S141381232009000800018

19. Oliveira RL, Santos MEA. Educação em saúde na Estratégia Saúde da Família: conhecimentos e práticas 
do enfermeiro. Rev Enferm Integrada. 2011;4(2):833-44.

20. Bezerra IMP, Sorpreso ICE. Concepts and movements in health promotion to guide educational practices. J Hum Growth Dev. 2016;26(1):11-20. DOI: http://dx.doi.org/10.7322/jhgd.113709

21. Machado LDS, Ramos JLS, Machado MFAS, Antão JYFL, Santos SB, Marinho MNASB, et al. Participatory process of health promotion at school. J Hum Growth Dev. 2015;25(3):357-63. DOI: http://dx.doi. org/10.7322/jhgd.90637

This article is distributed under the terms of the Creative Commons Attribution 4.0 International License (http://creativecommons.org/licenses/by/4.0/), which permits unrestricted use, distribution, and reproduction in any medium, provided you give appropriate credit to the original author(s) and the source, provide a link to the Creative Commons license, and indicate if changes were made. The Creative Commons Public Domain Dedication waiver (http://creativecommons.org/publicdomain/zero/1.0/) applies to the data made available in this article, unless otherwise stated.

\section{Resumo}

Introdução: A adolescência é caracterizada como um período de transição no desenvolvimento entre a infância e a vida adulta que impõe grandes mudanças físicas, cognitivas e psicossociais. Frente a isso, o adolescente encontra-se exposto e vulnerável ao consumo de álcool e drogas, que tem sido um meio para a atuação do enfermeiro através do Programa Saúde na Escola (PSE). Nesse sentido, a interação entre educação e saúde pode influenciar os adolescentes a tornarem-se questionadores dos riscos a que estão expostos e alcançar em conjunto, uma melhor qualidade de vida.

Objetivo: Analisar a percepção e práticas de saúde dos Enfermeiros atuantes no Programa Saúde na Escola, frente ao uso de álcool e drogas na adolescência.

Método: Trata-se de um estudo descritivo, qualitativo realizado no município de Juazeiro do Norte, CE, tendo como participantes 18 enfermeiros atuantes no PSE. A coleta de dados ocorreu por meio de uma entrevista semiestruturada e a organização por meio de análise temática.

Resultados: Os participantes afirmaram que a importância de sua atuação está voltada para ações de prevenção ao uso de álcool e drogas entre adolescentes, excluindo os preceitos da promoção da saúde. Apontaram que a interação entre educação e saúde se caracteriza como estratégia eficaz na prevenção de danos causados pelo uso de álcool e drogas, ressaltando a participação dos familiares durante o processo de elaboração, aplicação e continuidade. Ainda evidenciou-se que as práticas educativas são realizadas em sua maioria através de palestras, caracterizando um trabalho centrado na prática clínica, individual e curativa.

Conclusão: Os enfermeiros compreendem que a interação entre saúde e educação consiste em uma estratégia eficaz na prevenção do uso de álcool e drogas no público adolescente, ressaltando a importância da participação dos familiares no processo de construção e apoio deste contexto. Porém, é possível identificar que as ações desenvolvidas por esses profissionais ainda se restringem a modificação de comportamentos inadequados, sem o compartilhamento de novos conhecimentos.

Palavras-chave: adolescente, drogas, programa saúde na escola, enfermeiro. 